\title{
Refleksie op twee pastorale modelle, Deel 2: Die pastor as luisteraar - die storiemodel
}

\author{
Yolanda Dreyer \\ Tydelik-deeitydse dosent:Departement Praktiese Teologie \\ Universiteit van Pretoria
}

\begin{abstract}
Reflection on two pastoral models, Part 2: The pastor as listener - the narrative model

This study focuses on pastoral interaction with women. Pastoral care and counselling with women takes place within hierarchical societal and church structures. In such societies those higher up in the hierarchy exercise power over others. The male perspective has been the dominant one. This article is a critical description and evaluation of Julian Müller's narrative model for pastoral counselling. The premise of this model is that identity and story are related. This forms part of what is known in a broader context as the hermeneutics of conversation. In pastoral interaction the life stories of people are associated or disassociated with stories in the Bible. The article pleads for symmetrical interaction in pastoral counselling. This means that women should not be sold out to patriarchal narratives in the Bible that devalue them. Contra-narratives in the Bible according to which women have equal access to God could play an important role in pastoral interaction.
\end{abstract}

\section{DIE BRANDPUNT}

Die Pretoriase praktiese teoloog Julian Müller (1996:[i]) bevind homself binne die "paradigma van die hermeneutiese pastoraat." Hy sluit aan by die pastorale model van Don Browning (1991). Browning (1991:34) verwys na die Praktiese Teologie as "practical wisdom." Müller (1996:5) definieer sy verstaan van Praktiese Teologie soos volg: "Praktiese teologie is die sistematies-gestruktureerde, voortgaande hermeneutiese proses waardeur gepoog word om menslike handelinge, wat verband hou met die verhale van die 
Christen-geloofsgemeenskap teologies te verhelder en te vernuwe." Hy gaan van die standpunt uit dat alle handelinge kommunikatief van aard is (kyk Müller 1996:16, nota 5). So 'n standpunt is 'n wesenlike komponent van die hermeneutiese benadering.

Müller (1996:2) vul doelbewus hierdie benadering aan met die kommunikatiewe handelingsteorie. Hy verwys na Habermas (1972:304) se insig dat geen kennis waardeen belangevry is nie. In sy konstruktiewe bespreking van Heitink (1993:18) se definisie van Praktiese Teologie wys Müller (1996:16, nota 6) op die leemte dat die verhalende element van kommunikasie nie in hedendaagse Praktiese Teologie toereikend aan die orde kom nie. Sy benadering is bewustelik narratief van aard (Müller 1996:3-5). Sy doelwit is gesinsterapie. Die kombinasie tussen hierdie doelwit en die narratiewe benadering sluit aan by die gedagterigting van Auerswald (1968). Laasgenoemde redeneer vanuit die perspektief van 'n "totale ekosisteem waarbinne die kommunikasieprosesse verloop" (Müller 1996:4).

Die begrip "ekosisteem" verwys na "sosiale ekologie, die ekologie van menslike sisteme" asook na 'n "filosofiese epistemologie" (kyk Auerswald 1987:322; Müller 1996: 13). Die vraag na die waarheid in hierdie benadering word nie beantwoord met vooringenome "objektiewe" uitgangspunte nie. Die kenproses geskied op 'n deelnemende wyse. So 'n proses veronderstel kommunikasie binne die "wyer ekosisteem" (Müller 1996:14). Dit is 'n benadering wat daarop fokus om die pastorant te "verstaan." Hierdie verstaansproses is alleen moontlik wanneer "'n mens in die betekenisgeheel opgeneem word" (Müller 1996:14). In so 'n pastoraat lê die klem nie op die rasionele kennisname van die mens se omstandighede nie. Dit is nie 'n "rasionele dialoog" nie, maar gaan om ervaring (Müller 1996:15).

Die pastor en die persone in terapie word mede-konstrueerders van 'n gedeelde realiteit. Die pastor is hiervolgens nie die enigste en onfeilbare verteenwoordiger van die "waarheid" nie, maar 'n medespeler in die verhaal van die soeke na die waarheid. Die vrae wat hy of sy [die pastor] in die gesprek vra, is nie meer soveel gerig op: "Wat het werklik gebeur?" nie, maar op: "Hoe ervaar en interpreteer jy dit wat met jou gebeur het?"

(Müller 1996:16) 
In die narratiewe model van Müller (1996:19) gaan dit in die pastoraat om "verbindings" lê en nie om "blote handelinge" nie. Hy is geïnteresseerd in die "bedoeling" en "motivering" wat agter die handelinge lê. Daarom is die vraag na die groter werklikheid waarin mense eksisteer, van belang. Met behulp van 'n "narratiewe kyk op die werklikheid" word daar in die pastoraat gevra na die "hele storie" van menslike eksistensie. Die teologie, psigologie en sosiologie verskaf wel waardevolle insigte, maar is nog nie die hele verhaal nie (kyk Müller 1996:20). Die perspektief van die narratiewe teologie help om die leemte te vul: 'n mens se lewe word in storievorm ervaar. "'n Storie is ... ' $n$ beskrywing en verklaring vir waarom dinge is soos dit is. Daarom is dit ook heeltemal moontlik dat jy God kan raakloop in die proses van die vertel van jou storie" (Müller 1996:21). Mense is gedurig besig om die invloede op hulle lewe in die vorm van stories te organiseer. Hierdie insigte van die narratiewe teologie ontleen Müller aan die werk van G W Stroup (1981).

Stroup (1981:111) wys daarop hoe identiteit en storie in mekaar se verlengstuk lê. 'n Mens word deur ander geken wanneer hulle jou storie ken. Elke mens het 'n "kernstorie" (Müller 1996:23). Rondom die kem figureer aspekte van die mens se lewe, soos byvoorbeeld die lewe in die huwelik, die rol van materiële goed, die arbeidsituasie en seksualiteit. Al hierdie ander aspekte kan 'n rol speel in en beslis die kernstorie. In die kommunikasie tussen die pastor en die pastorant is die krisis waaraan die pastor aandag gee, nooit in isolasie nie. "'n Pastor moet 'n aanvoeling, 'n passie, 'n bewondering hê vir die stories van die lewe en hy [of sy] moet veral in vervoering wees oor die storie van God met mense” (Müller 1996:25). Müller (1996:24) verkies daarom om die pastorale interaksie te beskryf in terme van betrokkenheid. Hy meen dat mense se ontmoeting met mekaar 'n te alledaagse aangeleentheid is. Werklike verstaan bring 'n "gebeurtenis van betrokkenheid op dreef' (Müller 1996:25).

Die betrokkenheid van die pastor by die mens is nie om aan die mens sin te gee nie, maar om "egte, betekenisvolle soeke na sin" (Müller 1996:27) te fasiliteer. Vir die gelowige is die geloofsgemeenskap die ruimte waarbinne lewensin ervaar word (Müller 1996:26). Sin is egter nie noodwendig konstant nie. Die moontlikheid is altyd daar dat die mens sin kan verloor. Daarom moet dit telkens "opnuut vanuit die kernverhaal van die lewe met die self onderhandel word" (Müller 1996:28). Praktiese teoloë soos 
Thurneysen (kyk Müller 1996:28) meen dat die pastor op 'n profeties-kerugmatiese manier deur vermaning moet probeer om die mens tot sinvolle lewe aan te spoor. Ander meen dat die pastor dit passief-reflekterend kan doen deur die mens tot sinbelewing te begelei. Müller oordeel dat 'n geskikte werkwyse is om die verhale van mense en die verhale van die Christelike geloofstradisie op mekaar te probeer pas. Sodoende kan die mens die "potensiaal van verandering" wat al die tyd daar was maar tydelik onderdruk is, herontdek (Müller 1996:29). "Voordat die pastor se pastorale handelinge tot verstaan kan lei, moet daar eers 'n bepaalde spiritualiteitsvlak wees waarop die pastor funksioneer" (Müller 1996:30). Die "pastorale situasie" kan daarom as 'n "verhouding" gesien word. Müller (1996:33) beskryf dit as 'n "empaties-betrokke" verhouding. Hy verwys na Potts (1994:325) se gebruik van Martin Buber (1984) se bekende perspektief $e k-u$. Müller praat van 'n $e k-j y$ verhouding.

Spiritualiteit behoort nie 'n egosentriese gerigtheid te hê nie. Dit is 'n belewing van die transendente wat altyd van buite die mens is. Wanneer daar in die godsdiens ' $n$ $e k$-ek verhouding is, dit wil sê egosentries, het ons te doen met 'n godsdiens sonder spiritualiteit. Spiritualiteit vra 'n alter-gerigtheid - 'n gerigtheid op die ander. Marcus Borg ([1994] 1995:59, nota 28) is ook bekend vir sy gebruik van Martin Buber se konsep in sy Jesus-navorsing. Hy toon aan dat Jesus se verstaan van die koninkryk van God 'n gerigtheid is wat van 'n $e k-u$ verhouding spreek. 'n $E k$-ek verhouding getuig daarvan dat lewensin in menslike maatreëls gesoek word. 'n Spiritualiteit waarin die $e k-u$ verhouding sentraal staan, spreek van oorgegewe wees aan God. Buber verwys na 'n verhouding tussen die mens en die transendente (God). Buber (1984:8) formuleer dit soos volg: "(D)as Reich des Du hat anderen Grund ... Wer Du spricht, hat kein Etwas zum Gegenstand. Denn wo Etwas ist, ist anderes Etwas, jedes Es grenzt an andere Es, Es ist nur dadurch, daß es an andere grenzt. Wo aber Du gesprochen wird, ist kein Etwas. Du grenzt nicht." Müller (1996:33) gebruik die konsep "ek-U” maar, anders as Buber wat daarmee die verhouding mens-God bedoel, pas Müller dit toe op die verhouding mensmens ("ek-jy"). Hy maak hierdie verhouding van toepassing op die pastorale interaksie.

Müller (1996:54-58) gee te kenne dat hy terdeë bewus is van die invloed van die post-moderne paradigmaskuif op die kerk en die samelewing. Hy lê daarom klem op die "herstel van heelheid in die pastoraat" (Müller 1996:38). In Müller se narratiewe model 
word besondere ruimte gegee vir mense se verhale. Die ekosistemiese perspektief impliseer dat mense se krisisse opgelos kan word as dit ingetrek word in die "groter verhaal." Die fasilitering van sin vind dus plaas wanneer kleiner verhale 'n heel verhaal word. Voigens Müller (1996:101-102) is die grond van sy narratiewe model te vind in die oortuiging dat die menslike verhaal sin maak as dit deel is van iets groters, van 'n eenheidsverhaal.

\begin{abstract}
Verandering vind plaas deur die twee stories wat nie wil saamvloei nie weer en weer te herstruktureer (oorvertel en herinterpreteer) totdat dit in één storie ontwikkel .... Aan die hand van die elemente van 'n verhaal word 'n persoon of ' $n$ gesin tot die vertel van die volle verhaal gelei .... Daarom word mense gelei om hulle verhale op so ' $n$ wyse te vertel en te hervertel dat daar uiteindelik herinterpretasie en rekonstruksie plaasvind.
\end{abstract}

(Müller 1996:102, 104)

Hy sluit by Stroup aan wat insien dat daar in die geloofsgemeenskap 'n "botsing van stories" (Müller 1996:173) voorkom: “... The narrative of Christian confession or autobiography emerges from the collision between individuals and their personal identity narratives and the Christian community and its narratives" (Stroup 1981:91). Volgens Müller (1996:173) is die "uitdaging van die pastoraat en die pastor ... om hierdie 'botsing' vrugbaar te maak." Riet Bons-Storm (1989:63) beskryf dit as die "kruispunt van hermeneutiese sirkels."

Müller en Bons-Storm sluit aan by die post-moderne denke se klemtoon op die holistiese perspektief op die samelewing. Die Nederlandse teoloog, H Stufkens (1987: 185), formuleer hierdie belangrike insig soos volg:

De holistische visie gaat ervan uit dat een deel van dat grote geheel niet op zichzelf te begrijpen is, maar slechts vanuit het geheel. Dat geheel is meer dan de som der delen. Wie het deel niet in het geheel ziet, ziet het deel in het geheel niet! Essentiëel is inzicht in de organische samenhang, de totale structuur, de "gestalte", het systeem: die leveren de noodzakelijke context voor begrip van de deien ... voor hen die zich hiermee bezighouden kenmerkt 
zich door het ontwikkelen van een "open mind" voor nieuwe zienswijzen en denkkaders (paradigma's), en de bereidheid om crises in eigen denken en leven onder ogen te zien als kansen op groei naar een nieuw zijns- en bewustzijnsniveau, om zich met ander waarden in een proces van "transformatie" te begeven ... processen van paradigma-verandering en transformatie zowel op persoonlijk als op maatschappelijk niveau.

Post-moderniteit moet egter nie gesien word as iets wat deur eenheidsdenke gekenmerk word nie. Kenmerkend van die nuwe paradigma is juis dat so 'n denke ontbreek. Die vorige (moderne) paradigma het klem gelê op die dele in terme van die geheel. In 'n narratiewe model gaan dit om die saamvloei van die kleiner verhale in 'n groter verhaal. Antropologies gesien, vind mense (of hulle individuele lewensverhale) sin wanneer hulle gesien word in terme van die groter geheel (die "meesterverhaal" - vgl Müller 1996:26).

Dit is egter belangrik om in te sien dat post-modeme denke nie as sodanig die klem lê op die sin wat die dele in verhouding met die ander dele binne die geheel het nie. Die deel word as geheel in sigself gesien. 'n Ekosisteem behoort eerder gesien te word as 'n netwerk van dele wat gehele in sigself is. Die bekende post-moderne denker Fritjof Capra (in Hölzle \& Janowski 1987:519) beskryf dit soos volg: "Wenn es um das Bild der Wirklichkeit geht, kann man es am besten als ganzheitlich-okologisches Weltbild bezeichnen. Man sieht die Welt nicht als ein mechanisches System - bestehend aus Grundbausteinen [dele] - sondern vielmehr als ein Netzwerk von Beziehungen."

In Müller se narratiewe pastoraat funksioneer die lede van 'n gesin soos "dele" wat funksioneel in 'n gesin as geheel is: Dit lyk egter asof daar nie genoegsaam op die selfstandigheid van die lede klem gelê word nie. Wanneer Muller (1996:38) verder poog om in die pastoraat alle dele van 'n mens se bestaan (materiële en geestelike; arbeids- en familielewe; seksualiteit en ander behoeftes vir gemeensaamheid) in geheel te beskou, verteenwoordig dit 'n visie wat op die grens tussen die moderne en die post-moderne lê, maar nog nie werklik in alle opsigte post-modem is nie. Die post-moderne era word deur toleransie gekenmerk. Müller se narratiewe model waardeer verdraagsaamheid. Müller gebruik David Tracy (1987:19) se konsep hermeneutiek van die gesprek as raamwerk. Hierbinne is verdraagsaamheid die vanselfsprekende grondhouding. Hiermee word 
geïllustreer dat Müller binne die post-modeme paradigma opereer. Wanneer egter te veel klem op die ongelyke verhouding tussen die pastor (as hulpverlener) en die pastorant (as ontvanger van hulp) gelê word, kan simmetrie in die pastorale interaksie in die gedrang kom (kyk Dreyer 1998a:634-639). Dit is die moderne era wat gekenmerk word deur 'n denkstruktuur van magsgeoriënteerde mentaliteit (kyk Spariosu 1987:61).

Post-moderne denke, daarenteen, adem die gees van deernis vir die $(A)$ nder (kyk weer Foucault, in Beukes 1996:233-251). Welch (1988:513) verwys soos volg na David Tracy se insig: "Tracy's work speaks most clearly of the need for honesty and openness to the voice of others and to the negative as well the positive legacies of our traditions." Post-moderne denke wil die mens sien as ingebed in 'n netwerk van verhoudings, maar dan in terme van die nie-dominerende rol van sosiale verbande wat uiteraard die familie en die kerk sal insluit (vgl Schoeman 1990:287-289).

\section{WAT IS DIE WAARHEID?}

Müller (1996:1) is "post-modern" in die opsig dat hy nie vanuit óf deduktiewe of induktiewe wyse redeneer.nie. Hy vermy doelbewus die onderskeid tussen meta-, basis-, en praktykteorie en verkies om gebruik te maak van 'n "geïntegreerde, sirkulêre model van heen-en-weer beweeg tussen praktyk en teorie." Dit is soortgelyk aan my voorkeur vir "'n intuïtiewe [abduksie/retroduksie] wyse van ken" (Elliott 1993:48; Woodson 1979:1). Müller se keuse om in hierdie interaksie die klem te lê op "narratiewe betrokkenheid," impliseer dat nie net die verhoudings tussen mense ter sprake is nie, nie net tussen pastor en pastorant nie, maar ook tussen God en mens (Müller 1996:45). Wanneer hy sê dat pastorale interaksie die doel het om mense te help "om tot VERHAAL te kom," het hy 'n "groter, wyer, allesomvattende verhaal" (Müller 1996:86) in die oog. Hy verwys na hierdie groter verhaal as 'n "meta-verhaal," 'n "grand narrative" (vgl Middleton \& Walsh 1993:39). "Sonder so 'n meta-verhaal kan jou eie verhaal net nooit sin maak nie. Dit bly 'n vladderende storietjie wat nêrens verbind is nie. Sonder die meta-verhaal is hoop nie moontlik nie" (Müller 1996:86). Müller wil dit sterk beklemtoon dat die "grand narrative" nie gesien moet word as 'n verhaal naas die mens se eie verhaal nie. Hierdie meesterverhaal is die verhaal van God se liefde. Müller (1996:87) formuleer dit soos volg: "Die liefde tot God is immers nie iets los en apart van intermenslike 
verhoudinge nie. Die wyse waarop ons verhouding met God gekonkretiseer word, is juis in ons onderlinge verhoudinge."

Dit lyk asof die singewende ruimte wat die kerk vir gelowiges bied, wesenlik deel uitmaak van hierdie visie van Müller. In die kerk word immers die groter verhaal van God se betrokkenheid by mense gekommunikeer. Müller praat daarom van 'n betrokkenheid in terme van twee konsentriese (ekosistemiese) sirkels. Die eerste sirkel is die ruimte wat die gemeente bied. 'n Pastorale interaksie vind dus nie waarlik plaas as dit net in 'n sekulêre konteks los van die geloofsgemeenskap geskied nie. Die gemeente "funksioneer as die voortgaande konteks van sorg" (Müller 1996:89), nadat die individuele interaksie tussen pastor en mens geskied het. Hy illustreer hierdie kruispunte van interaksie in terme van die beeld van die huwelik in Efesiërs 5:21 (kyk Müller 1996:87). Indien die mens volgens hom los gesien word van mekaar en los van die "verhaal met God," het ons te doen met 'n drastiese pluralisering van die samelewing (vgl ook Gerkin 1991:14).

Die realiteit van mense in 'n huwelik is een van "onderdanigheid in verhoudinge" (Müller 1996:87). Hierdie stelling word gebaseer op die woorde in Efesiërs 5:21: "Wees ... aan mekaar onderdanig." Müller (1996:87) meen daarom dat daar in die pastoraat erns gemaak moet word met "empiriese werklikhede van verhoudinge." "Om te vra watter kragte van lojaliteit, mag en toewyding daar werksaam is, is pastoraal verantwoord" (Müller 1996:87). Omdat die mens ook in interaksie met die groter verhaal en in die ruimte van die gemeente lewe, kan daar in die pastoraat verby die realiteit van "onderdanigheid" gekyk en "op die Prent agter die prent" gefokus word. Daarom kan die fokus op die "Goddelike dimensie" die mens tot die insig bring dat "konsepte soos lojaliteit en toewyding" in die pastoraat gebruik word om die negatiewe ervaring wat onderdanigheid skep, te relativeer. Efesiërs 5:21 lees dan in die lig van die knuispunte van meerdere hermeneutiese sirkels soos volg: "Wees uit eerbied vir Christus aan mekaar onderdanig."

Wanneer daar in die pastorale interaksie aandag gegee word aan die hantering van "botsende stories," en bogenoemde meerdere konsentriese sirkels in ag geneem word, is die vraag na die korrekte Skrifbeskouing ter sake. Stroup (1981:91) maak hieroor die volgende opmerking: "In Christian communities this identity narrative [die oorbrugging 
van botsings] consists of a 'text' which begins with the canonical history Christians call 'Scripture' and extends through the community's history into the present." Müller wil in hierdie verband nie die woord "botsing" gebruik nie. "In baie gevalle word die Verhaal van God nie as in botsing met die eie verhaal beleef nie, maar daar is aan die ander kant 'n probleem met die integrasie daarvan" (Müller 1996:174; my beklemtoning). In die pastoraat word 'n hermeneutiese proses aan die gang gesit wat dit vir mense moontlik maak om "hulle storie in die lig van dié Verhaal te interpreteer."

Volgens hom kan hierdie integrasie bereik word sonder die eksplisiete gebruik van die Skrif. Dit lyk asof hy bedoel dat die pastor nie noodwendig in pastorale interaksie uit die Skrif hoef te lees nie. Mense moet in die pastorale interaksie eerder gehelp word om in die ruimte van die geloofsgemeenskap "hulle identiteit in die narratiewe geskiedenis van Jesus van Nasaret" (Müller 1996:175) te ontdek. Hy lewer daarom 'n pleidooi vir "ewewigtige Skrifgebruik." "Dit gaan oor 'n teenwoordigheid wat iets van God se teenwoordigheid bemiddel" (Müller 1996:176). In die pastorale interaksie is dit nie nodig dat die pastor hom of haar op "enkele tekste" beroep nie. "Wat nodig is, is dat ons die oorspronklike Bybelse waardes moet herontdek en herformuleer" (Müller 1996:71). Müller sluit by Hiltner (1972:126-131) aan. Vir Hiltner gaan dit om die onderliggende waarde wat in die Bybel voorkom, te ontdek. Dit is 'n afwysing van “'n biblisistiese manier (om) met ... Bybelse gegewens om (te) gaan" (Müller 1996:53). Müller sien in dat die "Bybelse paradigma" ver van die teenswoordige omstandighede verwyderd is. "In die Bybel is daar byvoorbeeld stories oor bloedskande, owerspel en huwelikskonflik ten spyte van absolute patriargale domina[n]sie wat nie eintlik as morele riglyn gebruik kan word nie" (Müller 1996:53).

Daar kan tot op 'n bepaalde hoogte waardering vir die Skrifbeskouing wat in Müller se narratiewe pastorale model voorkom, betoon word. Hier is duidelik nie sprake van 'n objektiewe waarheidsbeskouing nie. Hoewel hy meen dat die Skrif nie altyd eksplisiet in pastorale interaksie hoef te figureer nie, geskied die interaksie egter nooit los van mense se verhaal met God nie. Dit lyk asof ons hier met 'n dinamiese beskouing oor openbaring te doen het. Dit is van betekenis dat hy praat van "'n Prent agter die prent." Bybelwetenskaplikes kan moontlik beswaar hê om 'n uitdrukking soos "dieperliggende waardes" te gebruik omdat 'n soort allegoriese interpretasie van die Bybël vermoed kan 
word. Dit is egter duidelik dat Müller nie dít bedoel nie. Sy klem lê op die ontdekking van waardes wat in die Bybel betuig word. Hierdie insig van Müller kan myns insiens op 'n besondere wyse verdiep word indien hy sy waardering vir die post-moderne denke 'n paar treë verder neem. Die insig in die verskeidenheid van die boodskap van die Bybel te doen het met botsende waardes. 'n Post-moderne Skrifbeskouing gee nie net erkenning aan so ' $\mathrm{n}$ realiteit nie, maar sien ook in dat daar ook verhale in die Skrif is wat getuig ' $\mathrm{n}$ van verwronge kommunikasie tussen God en mens.

Wanneer Müller pleit dat daar in die pastoraat 'n herontdekking van Bybelse "dieperliggende waardes" moet plaasvind, sou dit 'n wins wees om erkenning te gee aan die feit dat botsende waardes ook in die Bybel betuig word. Indien dit nie gebeur nie, sal daar in die pastorale interaksie met vroue nouliks gevorder kan word tot die ontdekking van ' $n$ simmetriese verhouding tussen mense onderling en die saam soek met vroue na 'n onbemiddelde toegang tot God waar geen manlike hiërargie belemmerend inwerk nie. Op só ' $n$ wyse kan die onkonvensionele evangelie van Jesus van Nasaret in reliëf geplaas geword (kyk Dreyer 1999:91-94).

"Waarheid is dus nie geleë in die Skrif as objek in sigself nie. Die skrywer van die Efesiër-brief sê dat "waarheid word in Jesus gevind" (kyk Ef 2:21). Pastorale interaksie het as doel om hierdie "waarheid" te bemiddel. Die "waarheid wat in Jesus" is, en wat in die Bybel in verskillende tipe verhale aanwesig is, vind op grond van die hermeneutiese en pastorale proses neerslag in die lewensverhale van mense vandag. Ek is daarom vervolgens geïnteresseerd om te sien hoe Müller die "bemiddelende rol" van die pastor beskryf.

\section{DIE BEMIDDELAAR?}

Alle "lewensverhale" is in 'n bepaalde kulturele konteks ingebed. Stroup (1981:109; vgl Muller 1996:208, nota 14) verwys hierna as die "social nexus." Die kulturele konteks het 'n beslissende invloed op mense se persoonlike identiteit. Die pastor deel ook in hierdie kulturele konteks. 'n Kultuur bestaan uit 'n "simbolesisteem." Müller (1996:160) haal Hiebert (1990:37) soos volg aan: "Persons within a cultural tradition share common symbols with common understandings." Kultuur bestaan ook uit meer as een samelewingsverband. Müller is in sy boek in die besonder geïnteresseerd om sy narratiewe 
model op die gesin as samelewingsverband toe te pas. Dit is egter belangrik om te besef dat familielewe net een van 'n hele aantal samelewingsverbande uitmaak. Waar die familielewe in die leefwêreld van die Bybel die belangrikste sosiale instelling was (kyk Malina [1981] 1993:117-148), is dit nie vandag die geval nie. Vandag oorheers die ekonomie en die politiek die kulturele lewe van mense in die Weste. Die moderne mens leef in kompartemente. Godsdiens word grootliks beperk tot Sondae. Müller se gesinsterapie beoog om die gesinslewe sterk aan die geloofsgemeenskap te koppel. Hy maak erns met die feit dat "elke individu (insluitende die pastor) se storie ... in die storie van ander ingebed" is (Müller 1996:160).

"Narratiewe betrokkenheid" vra van die pastor "meer as net 'n neutrale luister na die ander se verhaal, maar 'n gewilligheid tot betrokkenheid by die ander se verhaal" (Müller 1996:161). Dit vind plaas wanneer daar ' $n$ "doelbewuste en empatiese inbeweeg in die ander se kulturele sisteem" plaasvind. Die pastorale interaksie het "herstrukturering" (reframing) in die oog. Die pastor, meeluisterend betrokke, moedig mense aan om die "neerdrukkende probleme wat hulle ervaar, te objektiviseer en te personifieer" (Müller 1996:165). Hierdie proses van "eksternalisering" is ' $n$ voorwaarde vir herstrukturering. Dit stel mense in staat om hulle "los te maak van [daardie] dominante stories wat hulle lewens en verhoudinge gedurig vorm" (Müller 1996:166). Sodoende word die moontlikheid geskep dat mense "hulleself, mekaar en hulle verhouding op 'n nuwe manier" kan beskryf.

Hierdie pastorale interaksie lei tot 'n aantal positiewe gevolge:

- om onproduktiewe konflik te verminder;

- om die gevoel van mislukking te ondermyn;

- om mense te help om probleme saam (in dialoog) te hanteer;

- om persone in staat te stel om afstand te kry van hulle probleem sodat hulle iets daaraan kan doen.

Die bemiddelende rol van die pastor het in hierdie narratiewe model 'n duidelike kommunikatiewe funksie. Post-moderne kommunikasie vereis 'n simmetrie in die interaksie. Hierdie post-modeme paradigma het dit ook duidelik laat word dat 
institusionalisering die neiging het om verhoudings te verwring en dan verdwyn simmetrie. Müller se waardering vir die kulturele bepaaldheid van die pastorale interaksie spruit uit hierdie insig voort. Hy bring aspekte soos "konflik", "gevoel van mislukking," "gebrek aan samewerking," "onvermoë om genoegsaam afstand van probleme te kry," egter nie direk in verband met die negatiewe uitwerking van institusionalisering nie. Herstrukturering kan myns insiens eers plaasvind wanneer die skadelike uitwerking van kulturele maatreëls ingesien word.

Volgens die post-moderne visie het dekonstruksie ("herstrukturering") nie nuwe strukture as sodanig ten doel nie, hoewel nuwe strukture natuurlikerwys weer ontstaan. Herstrukturering is volgens hierdie visie om krities met die strukture om te gaan. Die doel is om die negatiewe waardes wat in bestaande strukture werksaam is, aan die kaak te stel. Mense kan sinvol begin lewe wanneer hulle hulle uitgelewerdheid aan die kultuur insien, negatiewe invloede identifiseer en probeer om in simmetriese verhoudings te bestaan. Die kommunikatiewe handelingsteorie het die hermeneutiese benadering op ' $n$ kritiese wyse nog verder gevoer. Die kritiese teorie laat nie toe dat verwronge kommunikasie wat werksaam is in strukture, onbevraagtekend gelaat en deur die hermeneutiese proses selfs verder voortgesit word nie. Die pastorale interaksie het myns insiens 'n bewusmaking van negatiewe ervarings in die oog. Dit geld vir beide pastor en pastorant. Die vraag is in hoeverre Müller se narratiewe model van pastorale interaksie kan help in 'n praktykteorie wat beoog dat vroue deur middel van die pastoraat 'n sinvolle lewe voor God kan vind.

\section{DIE UITKOMS}

Ek het groot waardering vir Müller se uiteensetting van 'n narratiewe benadering in die pastoraat. Hy maak erns met die veranderende omstandighede van die dag wat nuwe eise stel aan die pastoraat. Die wyse waarop hy die nuwe wêreld in ag neem, is om weg te beweeg van 'n oorbeklemtoning van dogmatiese konstrukte. Hy bedink die pastoraat eerder in terme van die lewe in die vorm van stories. Die waarheidselemente wat die kerk "leer," kan vandag met baie groter effek gekommunikeer word wanneer die estetiese nader aan die sentrum van menswees gebring word. Post-modeme denkers het met groot oortuiging aangetoon dat onder andere stories die lewe verwoord. Om die lewe net 
intellektueel te wil verstaan, is om by die verhaal van 'n mens, gevul met vreugde en ook pyn, verby te kyk. In die "narratiewe teologie" word daar nagedink oor die storie van die mens wat saamvloei met die storie van God se verhouding met die mens (in dogmatiese sin: die verbond). Müller het hierdie insigte myns insiens met groot sukses in die pastoraat toegepas.

Die post-moderne paradigma het ook gelei tot die waardering van die rol wat kommunikasie vervul in die pastorale interaksie. In die konteks van die post-moderne paradigma, wat die pastorale interaksie met vroue betref, het 'n kommunikasie wat op simmetrie gebaseer is, voorwaarde geword. Hierdie saak sal daarom in 'n narratiewe model ook sentraal moet staan. Kommunikasie geskied nooit vry van belange nie. In die pastoraat is die vra na belange, waardes en waarheid daarom belangrik. Epistemologie en pastoraat kan nie van mekaar geskei word nie. Wanneer die pastorale interaksie geskied vanuit die oorheersende belange van die pastor, of die kerk, of die dogmas, of die kultuur, kan simmetriese kommunikasie nie plaasvind nie. Müller se waardering vir 'n "epistemologie van betrokkenheid" is daarom verblydend. Hier het ons te doen met 'n gelyke saam luister in die soeke na wat waarheid is.

In Müller se uiteensetting van sy waarheidsbeskouing, kom teologiese sake uiteraard sterk na vore. In die pastoraat gaan dit immers nie net om die "goeie lewe" nie, maar om outentieke lewe voor God. Dit is 'n waardevolle insig in post-moderne denke dat die kompartementalisering van die lewe in die moderne era nie meer gehandhaaf kan word nie. Die "heil" en die "welsyn" van die mens is nie absoluut van mekaat te skei nie. Vanuit 'n Reformatoriese perspektief is die vraag na die plek wat die Bybel in die Godmens verhouding inneem, vanselfsprekend. Müller wys tereg biblisisme af. Sy Skrifbeskouing is kongruent met sy narratiewe model.

Dit is problematies dat Müller in die uitwerk van " $n$ "narratiewe teologie" nie heeltemal bereid was om saam te stem dat die "botsings" tussen God en mens van dieselfde intensiteit is as dié tussen mense onderling nie. Wanneer die mens byvoorbeeld nie reg laat geskied aan God se geregtigheid nie, kom dit neer op ' $n$ botsing met Goddelike waardes en het dit ' $n$ konkrete uiwerking op intermenslike verhoudings van asimmetriese aard. Die simboliese universum (die Godsverhaal) staan in 'n dialektiese verhouding met die sosiale universum (die mens se verhaal). Outentieke lewe voor God 
(heil) is ineengevleg met die onderlinge simmetrie tussen mense (heling). Müller se versagting van die "botsings" in die God-mens verhouding het myns insiens te doen met ' $n$ bepaalde Godsbeeld en Skrifbeskouing. Die kontekstuele teologie en feministiese hermeneutiek het duidelik aangetoon dat Godsbeelde hand aan hand gaan met Skrifbeskouing en verwronge kommunikasie (kyk Dreyer 1998b). Die botsings in die lewe wat voortspruit uit hiërargiese strukture, hou verband met 'n Godsbeeld waar liefde onderbeklemtoon en dominansie oorbeklemtoon word. Die Bybel getuig van beide sulke Godsbeelde. Dit lyk of Müller se Skrifgebruik in die pastoraat daarop neerkom dat die mens se lewensverhaal bloot maar net met die Godsverhaal moet integreer. In die lig van die kontekstuele teologie en feministiese hermeneutiek is so 'n standpunt te simplisties.

In 'n meer genuanseerde Skrifbeskouing word ingesien dat die Bybel meesternarratiewe en kontra-narratiewe (kyk Breytenbach 1997:1157-1182) het. Hierdie verhale is nie noodwendig altyd in ooreenstemming met die evangelie van Jesus van Nasaret nie. Müller lê tereg klem op 'n Skrifbeskouing in die pastoraat wat erns maak met Jesus van Nasaret. Die pastor se "bemiddelende funksie" onder andere te doen met die bewusmaking van die botsende Godsbeelde en lewensverhale (kyk Dreyer 1998b). Hoe anders sal mense hulle lewens in die lig van die evangelie kan herstruktureer? Müller het uitgewys dat hierdie bemiddelende funksie plaasvind in 'n gedeelde kultuur. Hy het egter nie die post-moderne insig genoegsaam beklemtoon dat kultuur institusionaliserend inwerk op mense se lewensverhale nie. Herstrukturering behsort nie die skep van "gesonde" strukture as sodanig in die oog te hê nie. Nuwe strukture word gevorm deur "gesonde" verhoudings. Maar strukture lei altyd weer tot institusionalisering en die moontlikheid van verwringing. Vir my gaan dit dus om die bewuswording van die waardes wat verskuil lê in "gedeelde kultuur" en wat lei tot 'n gebrek aan insig in wat ten grondslag van konflik lê (kyk Dreyer 1998b:565-570).

'n Ongenuanseerde Skrifbeskouing werk nie met die insig dat meester-narratiewe en kontra-narratiewe in die Bybel voorkom nie. Dit lei daartoe dat die "verwronge kommunikasie" wat verskuil lê in strukture (ook in die leefwêreld van die Bybel), nie in verband gebring word met botsende stories oor God en mense nie. Müller gee besondere aandag aan die gesin as struktuur. In die Bybel vind ons egter verskillende voorstellings van die familie en die huwelik as instelling. Huweliksmaatreëls het in opeenvolgende tye 
in hierdie leefwereld verander omdat die Godsbeeld in byvoorbeeld die monargale periode nie meer dieselfde was as in die na-eksiliese reinheidsideologie nie (kyk Malina 1993:159-161). In die monargale periode waar God as dié Monarg voorgestel is, het onder andere die koning "vreemde vroue" in sy huishouding ingeneem om sy en God se mag uit te brei. In die na-eksiliese periode het die beskouing oor die "heiligheid" van God gelei tot verpligte egskeiding van die "onrein" vroue (kyk Bossman 1979). Pilch (1988:64) verwys soos volg hierna:

(The) rules in Leviticus 11-15 listing and explaining why certain things are clean and unclean ... derive from the post-exilic era (after 537 BCE) or approximately contemporaneous with Esra's determination to restore holiness to the community by dissolving "mixed-religion" marriages (Ezra 10:10-11). Society was deeply concerned about being "holy like the Lord is holy" and purifying marriages seemed one way to restore and maintain a holy community.

In die Nuwe Testament het Jesus hom uitgespreek teenoor hierdie huweliksmaatreëls (Mark 10:1-12). In hierdie gedeelte sê Jesus (v 5): "Dit is oor die hardheid van julle harte dat hy [Moses - kyk na die huweliksmaatreëls in die boek Esra na aanleiding van die konvensies van die wet] hierdie bepaling vir julle gemaak het. Maar van die begin af, van die skepping af [kyk die boek Genesis se skeppingsverhale], 'het God hulle man en vrou gemaak'." Hier het ons 'n duidelike voorbeeld van 'n verhaal (die Esraverhaal) wat in die Bybel voorkom, maar nie in ooreenstemming is met die evangelie van Jesus van Nasaret nie. Jesus neem duidelik standpunt in téén die Kronis se huweliksbepalings (in die boek Esra) en kies vir die Deuteronomis (die verwysings in die boek Genesis).

In die Nuwe Testament is Paulus se visie oor die egalitêre verhouding van man en vrou in hulle teenwoordigheid voor God (Gal 3:28) nie dieselfde as dié van óf Esra óf selfs die outeur van die Efesiërbrief wat van Paulus gebruik maak nie. Die skrywer van Efesiërs leef in 'n wêreld toe die geloofsgemeenskap reeds begin institusionaliseer het. Iets van Paulus se visie op die eerbied wat daar vir Christus moet wees in die man-vrou verhouding, word wel gekommunikeer (Ef 5:21). Maar die boodskap word ingebed in 
die hiërargie van kulturele maatreëls. By Paulus vind ons egter 'n direkte aansluiting by die Jesus-saak (kyk Dreyer 1999:70-96). Die Pauliniese verhaal (ingebed in ' $n$ niegeïnstitusionaliseerde struktuur) en die Efesiër-verhaal (ingebed in 'n geïnstitusionaliseerde struktuur) is nie heeltemal kongruent nie.

In die pastorale interaksie, veral met vroue, kan daar nie maar net verwag word dat mense hulle lewens moet herstruktureer deur dit te integreer met 'n "monolitiese" Godsverhaal in die Bybel nie. In die pastorale interaksie behoort dit eerder te gaan om 'n bewusmaking van wat dit werklik beteken om in eerbied vir Christus te lewe. Paulus staan baie nader aan die Jesus-saak, 'n evangelie wat nie mense oproep om met strukture te integreer nie - maar om in strukture outentiek voor God te lewe. Strukture, byvoorbeeld die Jerusalemse tempelinstituut en die institusionaliserende kerk, behoort nie as "heilsinstelllings" te funksioneer nie. Binne die ruimte van instellings, byvoorbeeld die tempel en die kerk, ervaar mense die heilsame teenwoordigheid van God. Die instelling as sodanig genereer nie "heil" nie. Dit is dus onversoennaar met die Jesus-saak dat byvoorbeeld die tempel as die beeld van God se teenwoordigheid beskou is. Ook ander beelde wat in die teologiese tradisie vir God gebruik is, het dikwels gebots met wat in Jesus as God se ewebeeld (kyk Heb 1:3) sigbaar geword het. Die evangelie vra nie net dat mense in die lig van die Jesus-saak beelddraers van God moet wees nie, maar ook dat hulle in hulle interaksie met Ander, God se liefde sal verbeeld.

Vroue het in 'n oorheersend manlike wêreld hulle identiteit verloor. Maar ook vroue vind hulle identiteit terug in die lig van Jesus. Daar behoort nie in die pastorale interaksie só met vroue gekommunikeer word dat hulle verhinder word om die outentieke lewe wat vir hulle by God in en deur Jesus Christus is, te herken en daarvolgens te lewe nie. Die pastor het die taak om deur middel van simmetriese pastorale interaksie 'n konteks te help skep waarin outentieke lewe vir vroue moontlik word. Die storiemodel bied heelwat geleenthede. Deur werklik te luister na die verhale van vroue, word hulle outentieke storie gebore. Vroue se stemme word gehoor. Vroue met outentieke lewe word volle medewerkers aan die restourasie van kerk en samelewing volgens die norme van God se koninkryk. Die egte verhale van vroue spreek van 'n spiritualiteit waarin vroue as volwassenes lewe - dit wil sê mense met 'n eie-identiteit wat as volwaardige subjekte in interaksie met God en medemens eksisteer. Die pastoraat het ten doel om 
hierdie diskoers te fasiliteer. Gehoorsaamheid aan die Jesus-saak in 'n post-modeme konteks bied 'n uitdaging aan die pastoraat met vroue.

\section{Literatuurverwysings}

Auerswald, E H 1968. Interdisciplinary versus ecological approach. Family 7, 202-215.

Beukes, C J 1996. Michel Foucault en die historisering van Anderswees. HTS 52(2\&3), 233-251.

Bons-Storm, R 1989. Hoe gaat het met jou? Pastoraat als komen tot verstaan. Kampen: Kok.

Borg, M J [1994] 1995. Als met nieuwe ogen: De historische Jesus en waar het op aan komt in het geloof van vandaag, vertaal deur P Ros. Meinema: Zoetermeer.

Bossman, D 1979. Ezra's marriage reform: Israel redefined. BTB 9, 32-38.

Breytenbach, A P B 1997. Meesternarratiewe, kontranarratiewe en kanonisering - 'n Perspektief op sommige profetiese geskrifte. HTS 53(4), 1157-1182.

Browning, D S 1991. A fundamental Practical Theology. Minneapolis: Fortress.

Buber, M 1984. Das dialogische Prinzip: Ich und Du. Zwiesprache. Die Frage an den Einzelnen. Elemente des Zwischenmenschlichen zur Geschichte des dialogischen Prinzips. Heidelberg: Verlag Lambert Schneider. (Lambert Schneider Tassenbücher.)

Dreyer, Y 1998a. Pastorale interaksie met vroue - gesien vanuit die beelde wat vir God gebruik word. HTS 54(3\&4), 544-572.

- 1998b. Feministiese hermeneutiek as kritiese teorie. HTS 54(3\&4), 623-651.

- 1999. Jesus en vroue. HTS 55(1), 70-96.

Elliott, J H 1993. What is social scientific criticism? Minneapolis, MN: Fortress.

Gerkin, C V 1991. Prophetic pastoral practice: A Christian vision of life together. Nashville: Abbingdon.

Habermas, J 1972. Knowledge and human interest, tr by J J Shapiro. Boston: Beacon. Heitink, G 1993. Praktische Theologie. Kampen: Kok.

Hiebert, P G 1990. Cultural anthropology. Grand Rapids, MI: Baker Book House. Hiltner, S 1972. Theological dynamics. Nashville: Abingdon. 
Hölzle, P \& Janowski, H N 1987. Für ein neues Weltbild: Gespräch mit Fritjof Capra. Evangelische Kommentare, 519-522.

Malina, B J [1981] 1993. The New Testament world: Insights from cultural anthropology. Revised edition. Louisville, K Y: Westminster/John Knox.

Middleton, J R \& Walsh, B J 1993. Theology at the rim of a broken wheel: Bruce Cockburn and Christian faith in a postmodern world. Grail 9(2), 15-39.

Müller, J C 1996. Om tot verhaal te kom: Pastorale gesinsterapie. Pretoria: RGN. (RGN-Studies in Praktiese Teologie.)

Pilch, J J 1988. Understanding biblical healing: Selecting the appropriate model. BTB $18,60-66$.

Potts, K 1994. Martin Buber's "healing dialogue": Marital therapy - a case study. The Journal of Pastoral Care 48(4), 325-340.

Schoeman, M J 1990. Holisme: Die herowering van 'n ou wysheid in 'n moderne konteks. HTS 46, 267-292.

Spariosu, M 1987. Allegory, hermeneutics, and postmodernism, in Calinescu, M \& Fokkema, D (eds), Exploring postmodernism, 59-78. Amsterdam: John Benjamins Publishing Comany.

Stroup, G W 1981. The promise of narrative theology: Recovering the gospel in the church. Atlanta: John Knox.

Stufkens, H 1987. Christendom en holisme: Een oriëntatie. Kosmos \& Oekumene 21(7), 184-190.

Tracy, D 1987. Plurality and ambiguity: Hermeneutics, religion, hope. San Francisco: Harper \& Row.

Welch, S D et al 1988. Revue Symposium: Tracy, D 1987, Plurality and ambiguity: Hemeneutics, religion, hope. New York: Harper \& Row. Theology Today 4, 496 519.

Woodson, L 1979. A handbook of modern rhetorical terms. Urbana, Il: National Council of teachers of English. 